\title{
Dysocjacja osobowości a terapia EMDR w zaburzeniach wynikających ze złożonej traumy: możliwości zastosowania w fazie stabilizacji.
}

\author{
Onno van der Hart \\ Wydział Psychologii Klinicznej i Zdrowotnej, Uniwersytet w Utrechcie, Utrecht, Holandia \\ Mariëtte Groenendijk \\ Główny Referent w Trauma Centre Transit, Ośrodek Zdrowia Psychicznego, Ermelo, Holandia \\ Anabel Gonzales \\ Program Traumy i Dysocjacji, Szpital Uniwersytecki A Coruña, Hiszpania \\ Dolores Mosquera \\ Centro LOGSPIC, Ośrodek Zaburzeń Osobowości, A Coruña, Hiszpania \\ Roger Solomon \\ Buffalo Center for Trauma and Loss, Buffalo, NY \\ Et al.
}

\begin{abstract}
Jak sugeruje poprzedni artykuł w niniejszym piśmie, znajomość i stosowanie teorii strukturalnej dysocjacji osobowości (TSDP) oraz towarzyszącej jej psychologii czynności może przynieść korzyści lekarzom stosującym terapię EMDR (odwrażliwiania za pomocą ruchu gałek ocznych) w leczeniu pacjentów ze złożonymi zaburzeniami potraumatycznymi. Wg teorii TSDP, dysocjacja osobowości jest główną cechą traumatyzacji oraz szerokiej gamy zaburzeń związanych z traumą, od prostego zespołu pourazowego (PSTD) począwszy, a skończywszy na dysocjacyjnym zaburzeniu tożsamości (DID). Wspomniana teoria może stanowić pomoc dla terapeutów EMDR w opracowywaniu dokładnego schematu ułatwiającego zrozumienie problemów pacjentów oraz przy tworzeniu i wykonywaniu planu leczenia. Uzgodniony model ekspercki w przypadku traumy złożonej to leczenie odwołujące się do faz, gdzie faza stabilizacji i przygotowania poprzedza leczenie traumatycznych wspomnień. Niniejszy artykuł koncentruje się na początkowej fazie stabilizacji i przygotowania, która jest niezwykle istotna dla bezpiecznego i efektywnego stosowania EMDR w leczeniu traumy złożonej. Najważniejsze zagadnienia to (a) praca z nieadaptacyjnymi przekonaniami; (b) przezwyciężanie fobii dysocjacyjnych oraz (c) szerokie zastosowania uaktywniania zasobów (resourcing).
\end{abstract}

Słowa kluczowe: dysocjacja, strukturalna dysocjacja osobowości, zaburzenia dysocjacyjne, EMDR, leczenie odwołujące się do faz, faza stabilizacji.

$\mathbf{M}$ etoda EMDR (odwrażliwianie za pomocą ruchu gałek ocznych), opracowana poczatkowo w celu leczenia zespołu stresu pourazowego (PTSD), jest coraz częściej stosowana $\mathrm{w}$ terapiach innych zaburzeń psychicznych, łącznie $z$ zaburzeniami bęacymi skutkiem traum złożonych, takimi jak złożone PTSD, pograniczne zaburzenie osobowości (BPD), jak również złożone zaburzenia dysocjacyjne, takie jak dysocjacyjne zaburzenie osobowości (DID) oraz zaburzenia dysocjacyjne gdzie

This article originally appeared as Van der Hart, O., Groenendijk, M., Gonzalez, A., Mosquera, D., \& Solomon, R. (2013). Dissociation of the Personality and EMDR therapy in Complex Trauma-Related Disorders: Applications in the Stabilization Phase. Journal of EMDR Practice and Research, 7(2), 81-94. Translated by Karol Nobis 
indziej niesklasyfikowane (DDNOS), Podtyp 1. W powiązaniu $z$ powyższymi opracowaniami klinicznymi dotyczaçcymi modelu adaptacyjnego przetwarzania informacji (AIP) (Shapiro, 2001), wystepuje tendencja do poszukiwania uzupełniających modeli teoretycznych, w szczególności dotyczących zastosowania EMDR w leczeniu złożonych zaburzeń powiazanych $z$ traumą mogacych w sposób dotkliwy i negatywny wpłynać na życie osób dotkniętych takimi zaburzeniami. Dlatego też Luber oraz Shapiro (2009) twierdza:

Gdy pracujemy z osobami najbardziej osłabionymi, jedną $z$ najważniejszych dla nas rzeczy jest korzystanie $z$ osiagnięć innych dziedzin. Im więcej $z$ nich czerpiemy, tym skuteczniej możemy działać. Aby zastosować metodęEMDR jako narzędzie psychoterapeutyczne $\mathrm{w}$ najszerszym możliwym zakresie zjawisk psychopatologicznych, jej teoretyczny model powinien łączyć neuropsychologie rozwojową z efektem skumulowania traumatycznych doświadczeń (s. 227-228).

Niniejszy artykuł, bedacy kontynuacją poprzedniego artykułu (Van der Hart, Nijenhuis \& Solomon, 2010), przedstawia teorie strukturalnej dysocjacji osobowości (TSDP) jako metody uzupełniającej, która uwzględnia kwestie neurobiologiczne i rozwojowe w kontekście próby zrozumienia traumatyzacji, często wiążącej się $z$ dysocjacją osobowości. W przypadku TSDP, zagadnienie dysocjacji nie odnosi sie tylko do zaburzeń dysocjacyjnych, przedstawionych w Podręczniku Diagnostyczno-Statystycznym Zaburzeń Psychicznych (Diagnostic and Statistical Manual of Mental Disorders), edycja czwarta (DSM-IV), ale jest traktowane jako nieudana integracja, leżąca u podstaw wszelkich zaburzeń wywołanych przez traume, łącznie z PSTD. Dlatego też teoria TSDP może stanowić ramy teoretyczne dla wszelkich takich zaburzeń.

Teoria TSDP jest traktowana jako kompatybilna z modelem AIP; może ona uzupełnić ten model, dostarczając wyjaśnień na temat różnych zjawisk wystepujących w czasie złożonych traumatyzacji. Niektóre $z$ tych zjawisk to dysocjacje traumatycznych wspomnień, które w wyniku tego są trudno dostepne; pacjent funkcjonujący na co dzień nie pamięta ich. To również istnienie szeregu zdysocjowanych czesści osobowości (zbliżone koncepcje to między innymi stany JA, dysocjacyjne stany ego, stany tożsamości (identity states), odmienne osobowości). Zdysocjowane cześci tego typu charakteryzuja sie różnym stopniem autonomii umysłowej, posiadaniem własnego punktu widzenia, obejmującego myśli, uczucia, emocje, a także postrzeganiem oraz działaniami behawioralnymi wobec siebie oraz wobec innych osób, w tym terapeuty. Cześsi opisują siebie, jako "Ja" i posiadają własną, świadomie odczuwana perspektywe pierwszej osoby (Nijenhuis $\&$ van der Hart, 2011). W bardziej złożonych przypadkach, cześci te moga posiadać własne imiona, a niektóre $z$ nich mogą być odbierane przez inne cześci, jako zupełnie odrebne byty, takie jak duchy, demony lub zwierzęta. Zdarzają się również pacjenci z cześciami dysocjacyjnymi, które wykazują bardzo ograniczone poczucie siebie, co jest opisywane przez zdysocjowaną, funkcjonująca w życiu codziennym cześśc, tj. pozornie normalną część (ANP), jako odczucie „nie ja” (por. Van der Hart, Nijenhuis \& Steele, 2006).

Zdysocjowane cześci mogą w sposób otwarty lub utajony wtrącać się w zabiegi prowadzone przez terapeute. Przykładowo, jeśli, w ramach założeń modelu AIP, terapia koncentruje się na przetwarzaniu pewnych dysfunkcyjnych wspomnień z jedną ze zdysocjowanych cześci, inne części mogą sprzeciwiać się takim działaniom $\mathrm{i}$ ingerować $\mathrm{w}$ nie (pacjent może słyszeć grożące głosy lub odczuwać dolegliwości somatyczne, nie ujawniając tego terapeucie). W takiej sytuacji istnieje ryzyko wystapienia dekompensacji, nadmiernego pobudzenia, lub blokady. W innych przypadkach określone wspomnienie traumatyczne może zostać podzielone pomiędzy kilka zdysocjowanych czesści, z których większość pozostaje ukryta. Przetwarzanie może początkowo wydawać się udane, ale w rzeczywistości aspekty doświadczenia traumatycznego, stanowiące źródło największego lęku i cierpienia - tzw. jądra patogenne, mogą pozostać nienaruszone przez procedury EMDR i pozostawać w izolacji, zakłócając codzienne funkcjonowanie. Jako przykład można przytoczyć przypadek pacjentki, która - po przetworzeniu wspomnienia $z$ dzieciństwa o próbach zadowolenia swojej matki oraz poczucia, że „nic nie było wystarczająco dobre” - doświadczyła ulgi w cierpieniu, a wskaźnik skali SUD (Subjective Units of Disturbance - Subiektywna Skala Dystresu) spadł do 0 . W ciągu tygodnia pacjentka zgłosiła wystapienie dystresu, dlatego w czasie kolejnej sesji terapeuta przywołał wspomnienie i poprosił pacjentke, by popatrzyła w oczy siedmioletniej dziewczynki z tego wspomnienia i spróbowała zauważyć, co ta odczuwała. To wystarczyło, by pacjentka doświadczyła nagle intensywnych emocji, co było dla niej niezwykle zaskakujące. Dzięki skoncentrowaniu sie na tym obrazie, jako na nowym celu możliwe stało się całkowite przetworzenie wszelkich dysfunkcyjnych doznań związanych z tym wspomnieniem. Wcześniej cześś ANP nauczyła się ignorować odczucia i potrzeby dziecięcej czesści, odzwierciedlającej związek pomiędzy depresyjną 
matką (zbyt przygnębioną własnymi problemami, by zwracać uwagę na swą córke) a pacjentką.

Obok poszukiwań modeli teoretycznych zgodnych z AIP, terapeuci EMDR pracujacy $z$ pacjentami $z$ trauma przewlekłą/ złożonązastosowali podejście odwołujące się do faz, które jest standardem opieki w takich przypadkach (np. Brown, Scheflin \& Hammond, 2008; Herman, 2002: Międzynarodowe Stowarzyszenie Badań Traumy i Dysocjacji - International Society for the Study of Trauma and Dissociation [ISSTD], 2011). Leczenie odwołujace sie do faz, opracowane przez Pierre'a Janet (1898; por. Van der Hart, Brown \& Van der Kolk, 1989), składa sie $z$ trzech faz: (a) stabilizacji, redukcji objawów i budowania umiejętności, (b) leczenia traumatycznych wspomnień; oraz (c) (re)integracji i rehabilitacji osobowości. Nie zawsze fazy te stosuje się w sposób ściśle liniowy (Courtois, 1999; Herman, 1992; Korn, 2009; Van der Hart i in. 2006): szczególnie w przypadku zaburzeń wynikających ze złożonej traumy zachodzi konieczność powrotu do wcześniejszych faz, jako formy progresu terapii.

Wielu terapeutów już łączy leczenie odwołujące się do faz z terapią EMDR w swej praktyce klinicznej (np. Fine \& Berkowitz, 2001; Forgash \& Knipe, 2007; Gelinas, 2003; Gonzales \& Mosquera, 2012; Hoffman, 2006; Korn \& Leeds, 2002; Lazrove \& Fine, 1996; Paulsen, 2007; Twombly, 2005). Dla jasności, należy pamietać, w jaki sposób wspomniane wcześniej trzy fazy leczenia odwołującego sie do faz odpowiadają ośmiu fazom standardowego protokołu EMDR (Shapiro, 2001): Faza 1 - stabilizacja, redukcja objawów oraz budowanie umiejętności - odpowiada Fazie 1 oraz 2 protokołu EMDR; Faza 2 - leczenie traumatycznych przeżyć odpowiada Fazie 3-8 protokołu, natomiast Faza 3 - re(integracja) oraz rehabilitacja osobowości, jest włączona w zakres terapii EMDR, jako składowa oceny wyników terapii, uczenia nowych umiejętności i budowania zasobów, stosowania odpowiednich protokołów (przykładami są protokoły fobii i niedawnych wydarzeń) jak również przetwarzania przeszłych wspomnień, aktualnych wyzwalaczy oraz dostarczania przyszłych wzorców dla adaptacyjnych zachowan.

Niniejszy artykuł kładzie głównie nacisk na kliniczne zastosowanie EMDR w pierwszej fazie leczenia (odwołującego się do faz) pacjentów, z zaburzeniami, będącymi skutkiem złożonej traumy. Połączenie TSDP oraz modelu AIP może być bardzo przydatne nie tylko dla zrozumienia problemów pacjenta, ale również przy podejmowaniu odpowiednich decyzji terapeutycznych. TSDP zapewnia wszechstronne ramy, pozwalające terapeutom EMDR sporządzić dokładną historie choroby, konceptualizacje przypadku oraz plan terapii. Artykuł koncentruje sie na procedurach mających na celu ograniczenie objawów, rozwój umiejętności oraz przygotowanie do pracy nad trauma. Kolejny artykuł będzie poświęcony bezpiecznemu i efektywnemu przetwarzaniu traumatycznych przeżyć w ramach EMDR w przypadku dysocjujących pacjentów.

\section{Teoria Strukturalnej Dysocjacji Osobowości w skrócie}

Wg teorii TSDP, jedną z cech zaburzeń potraumatycznych jest podział osobowości pacjentów na różne podsystemy lub zdysocjowane cześci, jak w opisie traumy psychologicznej T. A. Rossa (1941), bedacej „punktem załamania”. Opis ten wskazuje, że można dokonać konceptualizacji przeżyć traumatycznych jako nieudanej integracji, która obejmuje dysocjacje osobowości. Tego typu dysocjacje można wyleczyć, ale istnieje również niebezpieczeństwo ich pogłębienia. Każda ze zdysocjowanych cześci posiada własną podbudowe psychobiologiczną (Nijenhuis \& Den Boer, 2009; Nijenhuis, Van der Hart, \& Steele, 2002; Van der Hart i in., 2006) i - jak wspomniano wcześniej - cechuje się własną perspektywą pierwszoosobowa. Pacjenci różnią się liczbą pozornie normalnych części ANP (jedna lub więcej) oraz liczbą części emocjonalnych (EP). ANP są motywowane przez systemy życia codziennego, natomiast EP żyją $w$ czasie traumy, i komunikują się za pośrednictwem podsystemów mechanizmów obronnych, takich jak walka, ucieczka, zamrożenie, oraz (całkowita) uległość, które to mechanizmy zostały aktywowane w momencie doznawania traumy (opis tych cech - patrz Van der Hart $i$ in., 2010; Van der Hart i in., 2006).

Dysocjacja osobowości na skutek traumy może mieć różne stopnie złożoności. Pierwszorzędowa dysocjacja osobowości (primary dissociation) obejmuje jednącześć ANP orazjednąEP; dysocjacja drugorzędowa (secondary) obejmuje jedną część ANP oraz dwie lub więcej części EP; dysocjacja trzeciorzędowa (tertiary) to co najmniej dwie cześci ANP i EP. Z perspektywy teorii TSDP, terapeuta EMDR stosujący standardowy protokół EMDR przy dysocjacji pierwszorzędowej, zachęca pacjenta - jego ANP - do skoncentrowania sie na doświadczeniu traumatycznym, jako celu, a tym samym do reaktywacji EP. Na tym polega zasada „tkwienie jedną nogą w teraźniejszości a drugą w przeszłości” (Knipe, 2007). Artykuł koncentruje się nie tylko na PTSD (dysocjacja pierwszorzedowa); teoria TSDP może stanowić pomoc dla terapeutów EMDR w zrozumieniu określonych zjawisk występujących przy stosowaniu standardowego protokołu EMDR w przypadku prostej traumy; przykładami może być 
utrata podwójnej uwagi oraz ekstremalne unikanie (fobia) traumatycznego wspomnienia.

Gdy osobowość jest podzielona na więcej cześci, terapeuta EMDR stoi w obliczu innej sytuacji, w której znajomość TSDP może być najbardziej pomocna. Dlatego też w niniejszym artykule koncentrujemy sie na drugo- i trzeciorzędowej dysocjacji osobowości, które charakteryzują się bardziej powtarzalną, ostrą i długotrwałą traumatyzacją, zwłaszcza w dzieciństwie. W przypadku drugorzędowej dysocjacji osobowości, jedna czesśc ANP pozostaje skoncentrowana na życiu codziennym, ale dwie lub więcej cześci EP są zafiksowane na obronie i po ich pobudzeniu angażują się w ponowne przeżywanie, lub raczej rekonstrukcje traumatycznych zdarzeń.

Podział EP opiera sie czesto na nieudanej integracji pomiedzy stosunkowo mało widocznymi mechanizmami obrony - ucieczki, walki, zamrożenia i (całkowitego) podporządkowania. Niektóre EP mogą utrzymywać trudne do zniesienia przeżycia afektywne, takie jak wstyd lub dotkliwa samotność. Ten poziom dysocjacji jest na ogół charakterystyczny dla pacjentów ze złożonym PTSD, z wynikającą $z$ traumy osobowością typu borderline, oraz z DDNOS Podtyp 1. Podtyp ten obejmuje objawy kliniczne zbliżone do DID, nie spełniając wszystkich jego kryteriów (Amerykańskie Stowarzyszenie Psychiatryczne - [APA], 1994) - jest jednym $z$ najcześciej spotykanych zaburzeń dysocjacyjnych w praktyce klinicznej (np. Johnson, Cohen, Kasen \& Brook, 2006; Sar, Akyuz \& Dogan, 2007). Pacjenci z DID, u których często w historii choroby wystepuje chroniczne zaniedbanie interpersonalne, złe traktowanie i molestowanie we wczesnym dzieciństwie (Boon \& Draijer, 1993; Putnam, Guroff, Silberman, Barban \& Post, 1986) charakteryzuja sie trzeciorzędową dysocjacją osobowości, w której występuje więcej niżjedna część ANP oraz wiele cześci EP. Cześś ANP, motywowana przez systemy działania w życiu codziennym, może ulec podzieleniu w celu podtrzymania funkcjonowania w określonych i nieuniknionych sytuacjach, które moga przywoływać traumatyczne wspomnienia. Taki podział ANP może zachodzić wzdłuż granic różnych systemów działania codziennego życia. Przykładowo, ANP może rozwinaćc się u wykorzystywanego seksualnie dziecka nawet podczas czynności jedzenia - za pośrednictwem podsystemu regulacji energii - w trakcie śniadania spożywanego w obecności rodzica, który chwile wcześniej dopuścił się przemocy.

W teorii TSDP postuluje sie, że dysocjacja osobowości jest podtrzymywana przez serię fobii charakterystycznych dla osób, które doświadczyły traumy, a także czestokroć przez brak umiejętności integracji i wsparcia społecznego (Van der Hart i in., 2006). Pojęcie „fobia” dotyczy zazwyczaj zaburzeń lekkowych i jest rozumiane, jako uporczywy strach przed czynnikami zewnętrznymi (zwierzęta, sytuacje towarzyskie, itp.), których dana osoba stara się unikać. $Z$ drugiej strony, Janet (1904) opisał reakcje fobiczne zwrócone w kierunku przeżyć wewnętrznych, takich jak myśli, uczucia, fantazje itp. Osoby doświadczające długotrwałej traumy często przejawiają ogromny strach przed wewnetrznymi zachowaniami psychicznymi i towarzyszącą im treścią, jak również przed czynnikami zewnętrznymi, które mogą przywołać przeżycia traumatyczne (Steele, Van der Hart \& Nijenhuis, 2005; Van der Hart i in., 2006). Główna fobia podtrzymująca dysocjacje osobowości to fobia traumatycznych wspomnień, której najważniejszą składową jest unikanie całkowitego uświadomienia sobie traumy oraz jej wpływu na własne życie (Janet, 1904; Van der Hart i in., 2006). W przypadku chronicznej traumy zachodzi potrzeba zintensyfikowania procesu unikania behawioralnego i intelektualnego, stanowiącego element podtrzymywania dysocjacji osobowości, aby zapobiec temu, co czesśc ANP postrzega, jako szczególnie trudne do zniesienia uświadomienie sobie siebie samego, innych osób oraz świata. W konsekwencji, taka fobia podstawowa zdaje się być źródłem fobii o szerokim zakresie oddziaływania (Van der Hart i in., 2010; Van der Hart $i$ in., 2006).

Tego typu fobiczna aktywność psychiczna i behawioralna jest określana również, jako mechanizm obronny w psychodynamicznym ujęciu takich pojecć jak mechanizm unikania i idealizacji (np. Dell, 2009; Knipe, 2007). Aktywność taka może być postrzegana, jako działania zastępcze, co oznacza nie tylko działania mniej efektywne, które zastepują te bardziej efektywne, ale również (dużo) trudniejsze działania, które tworza zdrowie psychiczne. W działania te angażuja się zarówno czę́ci ANP jak i EP. Przezwyciężanie takiego zespołu fobii, jak również inne sposoby podnoszenia efektywności pacjentów (np. jakości ich działań intelektualnych i behawioralnych) oraz poziomu ich energii sa postrzegane, jako kluczowe elementy udanego leczenia. Tabela 1 przedstawia fobie powiazane $z$ traumą oraz sposoby radzenia sobie $z$ nimi w poszczególnych fazach leczenia.

\section{Model Adaptacyjnego Przetwarzania Informacji oraz TSDP: Uzupełniające się podejścia}

Zgodnie $\mathrm{z}$ modelem AIP, zdarzenia traumatyczne skutkują wspomnieniami przechowywanymi w sposób dysfunkcyjny, to znaczy są one izolowane i 
Faza 1: Redukcja objawów, stabilizacja i budowanie umiejętności

- Przezwyciężenie fobii przed przywiązaniem i utratą więzi, zwłaszcza z terapeuta;

- Przezwyciężenie fobii przed aktywnością psychiczną (np. przeżycia wewnętrzne, takie jak uczucia, myśli, doznania, życzenia, fantazje)

- Przezwyciężanie fobii zdysocjowanych części osobowości (ANP i PE)

Faza 2: Leczenie wspomnień traumatycznych

- Przezwyciężenie fobii przywiązania do sprawcy (sprawców)

- Przezwyciężanie fobii przywiązania w cześciach EP w odniesieniu do terapeuty

- Przezwyciężanie fobii dotyczącej traumatycznych wspomnień

Faza 3: Integracja osobowości i rehabilitacja

- Przezwycięzanie fobii przed normalnym życiem

- Przezwycieżanie fobii przed zdrowym podejmowaniem ryzyka i zmianą

- Przezwyciężanie fobii przed intymnością, w tym przed seksualnością oraz postrzeganiem ciała

Uwaga: ANP = pozornie normalna część osobowości; EP = emocjonalna czesść osobowości

niezasymilowane w ogólną sieć pamięci danej osoby (Shapiro, 1995, 2001). Jak wyjaśnia Shapiro (2001):

Struktura patologiczna jest nieodłącznym elementem, statycznej i niewystarczająco przetworzonej informacji, zachowanej w czasie zdarzenia traumatycznego . . . Brak odpowiedniej asymilacji oznacza, że pacjent wciąż reaguje emocjonalnie i behawioralnie w sposób spójny $z$ przeszłym zdarzeniem traumatycznym (str. 17).

Informacje przechowywane dysfunkcyjnie obejmuja wspomnienia ,zatrzymane w czasie” oraz zawieraja niedające się przystosować zachowania intelektualne i behawioralne, które były obecne w czasie, w którym nastapiła trauma, w tym reakcje sensomotoryczne, reakcje afektywne (np. jak ują to Janet - gwałtowne emocje (Janet, 1909), takie jak wszechogarniajacy strach, gniew, wstyd lub poczucie winy), przekonania, postrzeganie zagrożenia i przewidywania (tj. oczekiwania oparte na przeszłym niebezpieczeństwie i zagrożeniu doświadczonym podczas zdarzenia traumatycznego). Jak napisał Janet (1925):

(Traumatyczne) doświadczenie spowodowało zaburzenie, ponieważ uległo zdysocjowaniu. Istniało w izolacji, w oddaleniu od całości doznań i koncepcji, które tworzyły osobowość podmiotu; rozwijały sie w izolacji, bez kontroli i bez przeciwwagi; objawy chorobowe znikneły, gdy wspomnienie ponownie stało się częścią syntezy tworzacej jednostke (str. 674).

Określenie „zdysocjowany” użyte przez Janet’a (Janet 1925) oraz określenie „w izolacji” użyte przez Shapiro (Shapiro, 2001) odnoszą się do tego samego zjawiska. Mimo iż model AIP nie jest opracowaną teorią osobowości, to zwraca uwage na znaczenie uczenia sie, a tym samym na sieci pamięci, jako główne determinanty cech osobowości i zachowania (Shapiro, 1995, 2001; Solomon \& Shapiro, 2008). Stąd też doświadczenia przechowywane w sposób dysfunkcyjny (szczególnie u grup doświadczających chronicznej traumy) mogą być rozumiane, jako dysocjacja od reszty osobowości, która obejmuje szerszy system sieci pamięci leżacy u podstaw zachowania.

Teoria TSDP nie odwołuje sie do pojeccia „przechowywanej informacji”. Zamiast tego postuluje, że aktywności psychiczna i behawioralna, będące czesścią traumatycznych wspomnień, należą do pewnych świadomych i samoświadomych zdysocjowanych cześci osobowości, z których każda przejawia własną perspektywe pierwszoosobowa. Stosując zatem terminologie AIP, części EP oraz ANP posiadają własne sieci pamięci, przy czym w EP znajdują się wspomnienia przechowywane dysfunkcyjnie (zatrzymane w czasie). Dodanie koncepcji EP do założenia „dysfunkcyjnie przechowywanej informacji” poprzez podkreślenie faktu posiadania przez cześś dysocjacyjną perspektywy pierwszoosobowej, może pomóc terapeutom EMDR lepiej zrozumieć, jaki rodzaj przygotowania jest potrzebny $\mathrm{w}$ przypadku pojedynczej dysocjacji osobowości (trauma prosta). Dzieje się tak szczególnie wtedy, gdy EP wykazuje wysoki stopień niezależności, lub gdy pomiędzy cześciami ANP i EP wystepują intensywne fobie, którymi należy zająć się najpierw.

Traumatyczne przeżycia, które są ,przechowywane dysfunkcyjnie” leżą również u podstaw drugo- oraz trzeciorzędowej dysocjacji. Te poziomy dysocjacji mogą być prawdopodobnie bardziej dokładnie zrozumiane 
i opracowane fenomenologicznie za pomocą teorii TSDP. Teoria ta postuluje również, że traumatyczne przeżycia cześci EP mogąulec integracji (przetworzeniu) tylko wtedy, gdy są współdzielone przez zdysocjowane czesści. Innymi słowy, umiejętności cześci ANP (informacje adaptacyjne) muszą połączyć się $z$ dysfunkcyjnie przechowywanym wspomnieniem czesści EP. Aby zintegrować dysfunkcyjne i adaptacyjne neurosieci, zdysocjowane cześci, począwszy od ANP, muszą najpierw wytworzyć empatie oraz konstruktywną komunikację i współpracę między sobą, a bariery dysocjacyjne muszą być stopniowo usuwane. Przetwarzanie traumatycznych doświadczeń - jeśli jest udane - stanowi główny wkład we wspomnianą integracje.

\section{Leczenie odwołujące się do faz w przypadku drugo i trzeciorzędowej dysocjacji osobowości}

W przypadku drugo- i trzeciorzedowej dysocjacji osobowości, obejmujących szeroki zakres dysocjujących czesści, wymagana jest terapia odwołująca się do faz (Brown, Scheflin \& Hammond, 1998). W szczególności, przed rozpoczęciem leczenia traumatycznych wspomnień, należy skoncentrować terapię na stabilizacji, redukcji symptomów, w tym zachowań ryzykownych, oraz na budowaniu umiejętności. Wymaga to pracy z wewnętrznym systemem dysocjacyjnych czesści. W wielu przypadkach, podejście odwołujące się do faz można porównać do spirali, gdyż wymaga powrotu do motywów i przekonań zwiazanych z traumą, ponownej aktywacji reakcji i zasobów zaradczych oraz nieustannego mierzenia sie $z$ najistotniejszymi problemami. Przykładowo, może zaistnieć konieczność okresowej zamiany leczenia Fazy 2 (integracja przeżyć traumatycznych) na Fazę 1 (stabilizacja). Terapia EMDR może skorzystać na integracji założeń teorii TSDP w tej poczattkowej fazie, skoncentrowanej na stabilizacji pacjenta, zmniejszeniu objawów i zachowań ryzykownych oraz na przygotowaniu do przyszłej pracy nad trauma. Z drugiej strony, procedury EMDR mogą skrócić tą fazę i zwiększyć skuteczność terapeutyczna.

\section{Konieczność odpowiedniej diagnozy oraz} sporządzenia dokładnej historii medycznej

Bez odpowiedniej diagnozy terapeuci mogą założyć niższy niż w rzeczywistości stopień skomplikowania historii traumy oraz poziom dysocjacji osobowości, a tym samym nie uwzględnić różnych zdysocjowanych czesści, które powinny być włączone w terapie. W konsekwencji, terapeuci mogą nie zapewnić odpowiedniego poziomu stabilizacji i przygotowania. W ramach terapii EMDR, wielu autorów zwracało uwagę na zagrożenia w przypadku ignorowania tych problemów (Gelinas, 2003; Korn, 2009; Shapiro, 2001). Przykładowo, istnieje możliwość aktywacji nierozpoznanej cześci EP, która odtworzy inne traumatyczne przeżycia niż docelowe wspomnienie. Tego typu reakcje łańcuchowe obejmują intensywny strach $\mathrm{i} /$ lub gniew pomiedzy pozostałymi cześciami, prowadząc w końcu do ataków paniki, poważnych zachowań autodestrukcyjnych lub dekompensacji przytłoczonego pacjenta. Reasumując, EMDR może być stosowana w sposób efektywny i bezpieczny nawet w przypadku głęboko zdysocjowanych pacjentów pod warunkiem przeprowadzenia adekwatnej oceny, przygotowania-stabilizacji, redukcji objawów i budowania umiejętności.

\section{Leczenie odwołujące się do faz - Faza 1: stabilizacja, redukcja objawów oraz budowanie umiejętności}

Niezbędnym elementem wstepnym w leczeniu przeżyć traumatycznych w przypadkach złożonej dysocjacji jest (czasem dość długi) okres stabilizacji i rozwoju bardziej refleksyjnego funkcjonowania (Gonzales \& Mosquera, 2012), jak również efektywnego regulowania emocji oraz umiejętności relacyjnych i życiowych (Allen, Donagy \& Bateman, 2008; Brown i in., 1998, Courtois, 1999; Gelinas, 2003; Kluft, 1997, 1999; Korn, 2009; Linehan, 1993; Ogden, Minton \& Pain, 2006; Shapiro, 1995, 2001; Steele i in., 2005; Van der Hart i in., 2006). Ten pierwszy etap leczenia ma na celu poprawe jakości życia codziennego (w tym bezpieczeństwa i więzi), zwiększenie zdolności integracyjnych oraz powiązane $z$ tym poszerzenie okna tolerancji, poprawe współdziałania wewnętrznego oraz umiejętności radzenia sobie ze stresem w przypadku objawów PTSD i dysocjacji. Procedury i interwencje, które są konieczne aby osiągnąc te cele to psychoedukacja, rozwój elastycznej, empatycznej, kooperacyjnej więzi terapeutycznej o wyraźnie wytyczonych granicach, samoregulacja (regulacja afektywna i samouspokojenie), dbanie o siebie (w tym współczucie wobec samego siebie, umiejętność przebywania samemu, podstawowe gospodarowanie energia, rozwój codziennych zwyczajów i struktury oraz równowaga pomiędzy dbaniem o siebie i innych), zdolności interpersonalne; praca $z$ nieadaptacyjnymi przekonaniami (patrz również nastẹpny rozdział); uaktywnianie zasobów (w tym zasobów emocjonalnych, poznawczych, czuciowo-ruchowych i relacyjnych), strategie wzmacniania 'ego' oraz interwencje w celu wzmacniania pacjenta. Trudno opisać wszystkie typy procedur i interwencji w jednym artykule; ich opisy można znaleźć $\mathrm{w}$ innych publikacjach 
(np. Bonn, Steele \& Van der Hart, 2011; Forgash \& Copely, 2007; Gonzales \& Mosuqera, 2012; Twombly, 2000, 2005; Van der Hart i in., 2006). W niniejszym artykule skoncentrowano uwage na (a) pracy $z$ nieadaptacyjnymi przekonaniami (koniecznymi do instalacji pozytywnych przekonań $\mathrm{w}$ dalszym przetwarzaniu traumy); (b) przezwycieżaniu fobii dysocjacyjnych: głównej zasadzie leczenia w TSDP, która może ukazywać kierunek terapeutom EMDR podczas planowania i strukturyzacji terapii $\mathrm{z}$ takimi pacjentami, oraz (c) rozszerzonym zastosowaniu uaktywniania zasobów (standardowa terapia EMDR, która wymaga modyfikacji w przypadku leczenia osób, które doświadczyły ciężkiej traumy).

Podczas Fazy 1 istotnym elementem jest identyfikacja i leczenie nieadaptacyjnych przekonań i czynności behawioralnych (Van der Hart i in., 2006) różnych cześci ANP i EP. W przypadku pacjentów $z$ traumą złożona, tego typu przekonania sa głęboko zakorzenione i zazwyczaj wymagają uwagi już w fazie stabilizacji w przypadku leczenia odwołującego sie do faz. W teorii TSDP, te trudno adoptowalne przekonania postrzega sie jako zafiksowane, odruchowe działania behawioralne, które są nazywane substytucyjnymi działaniami intelektualnymi $i$ behawioralnymi (jak np. unikanie wszelkich osób, które w jakikolwiek sposób przypominają sprawce traumy, brak rozróżnienia pomiędzy rzeczywistością zewnętrzną i wewnętrzną lub między przeszłą a teraźniejsza). Takie działania stanowią substytut czynności adaptacyjnych w teraźniejszości. Pacjenci moga przejawiać fantazje substytucyjne, w których czesto są ratowani (przez rodzine lub terapeute), w których wystepuje pragnienie zmiany przeszłości i usunięcia „prawdziwej” przeszłości, pragnienie porzucenia odpowiedzialności i oddanie sie pod czyjąś opieke, nadzieja na otrzymanie magicznego leku, „złota fantazja”, w której każda potrzeba może być spełniona przez inną osobe oraz przekonanie, że zdysocjowane cześci nie należą do jaźni danej osoby. Każda $z$ tych fantazji służy jako obrona przed zmierzeniem się $z$ traumatyczną przeszłością oraz przeżyciem koniecznego żalu, który temu towarzyszy. Dlatego też przed pracą $z$ traumatycznymi wspomnieniami należy wyznaczyć pewien zakres celów terapeutycznych. Te przekonania substytucyjne są nierzeczywiste i powiązane $z$ uogólnionym brakiem uświadomienia sobie traumatycznych zdarzeń oraz ich wpływu na własną osobę i życie. Pacjenci przychodzący na terapię mogą nie uświadamiać sobie, jak ich historia (jeśli ją pamiętają) wiąże się ich aktualnymi problemami. Aby czynić postęp w leczeniu, terapeuci muszą wspomagać pacjentów w uświadamianiu sobie powiązań między przeszłością a teraźniejszością, ale również uczyć odróżniać je od siebie. Jest to trudne zadanie, zwłaszcza w przypadku osób, które doświadczyły ciężkiej traumy. Proces ten powinien odbywać się stopniowo i być przystosowany do umiejętności i motywacji pacjenta (dostosowanie tempa - pacing).

\section{Przezwyciężanie fobii związanych z traumą}

Możliwe jest przeprowadzenie stabilizacji, redukcji symptomów i przygotowania (Fazy I w leczeniu odwołującym sie do faz) poprzez systematyczne poświęcanie uwagi kilku fobiom powiązanym $\mathrm{z}$ trauma, które podtrzymują dysocjacje osobowości (Steele i in., 2005; Van der Hart i in., 2006). Fobie tego typu obejmuja (a) fobie relacyjne bliskości, porzucenia, straty i odrzucenia, zwłaszcza w odniesieniu do terapeuty; (b) fobie aktywności psychicznej, jak na przykład przejawianie określonych uczuć, doznań cielesnych, myśli, wyobrażeń, fantazji, życzeń i potrzeb; oraz (c) fobie zdysocjowanych cześci (które posiadają własne sztywne aktywności psychiczne oraz ukryte treści intelektualne, które mogą nie być akceptowane przez inne cześci). Istnieją inne fobie, które podtrzymują dysocjacje, w szczególności główna fobia wspomnień traumatycznych Przezwyciężanie takich fobii, mające miejsce w czasie drugiej i trzeciej fazy leczenia traumy, bedzie omówione w kolejnym artykule. Koncepcja fobii dysocjacyjnych, rozumianych w ramach teorii TSDP jako działania substytucyjne, jest powiązana z pojęciem obrony Knipe’a (2007), które jest przez niego traktowane jako dysfunkcyjnie przechowywana informacja.

Podstawowe podejście w zwalczaniu różnego rodzaju fobii to wspomaganie pacjentów W uświadamianiu sobie ich fobii, psychoedukacja i empatyczna eksploracja (Van der Hart i in., 2006). Porządek eksploracji zależy od stopnia ostrości fobii. Kierując sie systemami działania eksploracji, współpracy i troski, terapeuci wraz z pacjentami poszukują w sposób poznawczy elementów, których pacjent się lęka i których unika. Terapeuci włączają się w przeżycie pacjenta w sposób otwarty i wyrażajacy akceptacje. Tym sposobem terapeuci pomagają pacjentom zwerbalizować w najpełniejszy sposób ich lęki odnośnie przeżyć związanych $z$ określoną fobia. Zrozumienie celu obrony jest przydatnym elementem przygotowawczym do rozpoczecia Fazy 2 leczenia, w której obrona może stanowić punkt poczatkowy do uzyskania dostępu do traumatycznych wspomnień, tj. do dysfunkcyjnie przechowywanych sieci wspomnień.

Należy podkreślić, że przezwyciężanie różnych fobii podtrzymujących dysocjacje, niezależnie od 
jego systematyczności, nie wymaga określonej sekwencji. Przezwyciężanie takich fobii wymaga raczej jednoczesnej pracy $z$ inną fobią lub kilkoma $z$ nich. Przykładowo, przezwyciężanie fobii przywiązania i utraty wiezi wymaga, by pacjent otrzymał pomoc w przezwyciężeniu fobii dotyczacej dysocjujących cześci, ponieważ czesści te mogą być skonfliktowane ze sobą nawzajem $z$ powodu więi terapeutycznej.

\section{Przezwyciężanie fobii przywiązania i utraty więzi}

Nawiązanie elastycznej, empatycznej, nacechowanej współpraca więzi terapeutycznej o odpowiednio nakreślonych granicach jest niezbedne we wczesnej fazie terapii, podobnie jak praca nad innymi, bieżącymi związkami pacjenta, aby możliwe było stopniowe uzyskanie odpowiedniego poziomu bezpiecznego przywiązania (np. Kluft, 1993, 1997; Steele i in., 2001, 2005; Van der Hart i in., 2006).

Fobie relacyjne pacjenta przejawiają się również w relacji terapeutycznej, która przywołuje chroniczną zmienność działania systemów przywiązania i obrony zwiazanych $z$ krzywdzacym opiekunem, co stanowi podstawe głęboko lekkowych i zdezorganizowanych wzorów przywiązania (Liotti, 1999, Steele i in., 2001; Van der Hart i in., 2006). Podejście pacjenta może zmieniać się od ekstremalnego przywiązania do terapeuty, poprzez nieufność, aż do postawy defensywnej a nawet wrogiej, podczas których ma miejsce aktywacja różnych cześci osobowości. Z natury rzeczy, środkiem zaradczym dla tak mało bezpiecznych schematów przywiązania jest kontrola rekonstrukcji traumy relacyjnej w ramach związku terapeutycznego. Rekonstrukcje te wzbudzają intensywne emocje i skłonności do działań zarówno u pacjenta jak i terapeuty, dlatego też ważne jest określenie wyraźnych ram terapii. Przykładowo, niektóre EP moga przejawiać fobięprzed utratą więzi, a przez to mogą lgnać do terapeuty lub uporczywie szukać kontaktu ze sprawcą traumy lub innymi osobami, które mogą czynić im krzywde. Aby przezwycieżyć takie sytuacje, terapeuta musi przejawiać wysoki poziom umiejętności integracyjnych, zachowywać spokój i towarzyszyć pacjentowi $\mathrm{w}$ zrozumieniu tych przeciwstawnych tendencji, wynikających $z$ różnych cześci osobowości. Dlatego terapeuta powinien zachować przewidywalną i stabilną pozycję empatycznej ciekawości i współpracy, nie okazując postawy obronnej lub nie wdając sie $\mathrm{w}$ relacje $z$ pacjentem. Ustanowienie bezpiecznej więzi w związku terapeutycznym wymaga ram terapeutycznych, zapewniających bezpieczeństwo oraz mających spójne i wyraźne granice i ograniczenia.
Przezwyciężanie fobii dotyczącej działań psychicznych związanych z traumą

Pacjenci muszą stopniowo uświadamiać sobie, tolerować, rozumieć i personifikować (przejmować na własność) różne aktywności psychiczne lub przeżycia wewnettrzne, których do tej pory starannie unikali. Te aktywności psychiczne obejmują emocje, myśli, doznania cielesne, fantazje, potrzeby i wspomnienia. Przezwyciężenie takiej fobii przeżyć wewnętrznych jest konieczne aby zmierzyć się $z$ dostepem i przetworzeniem (integracja) traumatycznych wspomnień. Stopniowe przezwyciężanie tej fobii pociaga za soba zwiększenie regulacji afektywnej i funkcjonowania refleksyjnego oraz rozwój świadomej postawy, co według Shapiro $(1995,2001)$ jest przesłanką dla przetworzeniu traumy.

Należy zatem szkolić pacjentów, by akceptowali swe działania psychiczne bez przypisywania im osądów wartościującychorazby nauczylisięnajpierwzauważać, a potem zapobiegać tzw. „samoświadomościowym emocjom" (takim jak wstyd, strach lub obrzydzenie) jako reakcji. Terapeuci powinni czesto zacheccać pacjentów do uświadamiania sobie i eksplorowania swych bieżących doznań, tj. do bycia świadomym i do refleksyjnego działania w celu przyspieszenia procesu uobecniania (prezentyfikacji). Jest to szczególnie istotne podczas fazy stabilizacji, w której pacjenci uczą sie, jak identyfikować i radzić sobie $z$ wewnętrznymi i zewnętrznymi wyzwalaczami.

Dzięki instrukcjom dotyczacym wyobrażeniowego ograniczenia (containment imagery), terapeuci mogą pomóc pacjentom stworzyć w wyobraźni swoiste pojemniki w celu zatrzymania traumatycznych wspomnień. Wyobrażenia tego typu mogą przybrać postać sejfu w banku, dysku komputerowego, płyty DVD i tym podobnych (np. Brown \& Fromm, 1986; Kluft, 1993; Van der Hart i in. 2006; Van der Hart, Steele, Boon \& Brown, 1993). Pozwala to pacjentom tymczasowo „przechowywać” traumatyczne wspomnienia lub inne groźne przeżycia wewnętrzne. Techniki tego typu uczą pacjentów dostrzegać różnice pomiędzy nieadaptacyjnym unikaniem lub tłumieniem a zdrowym dostosowaniem tempa i czasu, które mogą kontrolować.

\section{Przezwyciężanie fobii przed zdysocjowanymi częściami}

Terapeuci powinni zachęcać do współpracy różne cześci dysocjacyjne, aby zmniejszyć sztywne podziały i zamknięcia między nimi. Leczenie fobii zdysocjowanych cześsi i ich różnych manifestacji, rozpoczyna sięod najbardziej dorosłej (dorosłych) cześsi osobowości pacjenta, zazwyczaj ANP. Terapeuta najpierw wzmacnia 
ANP poprzez uczenie jej umiejętności ugruntowania, regulacji, oraz funkcjonowania refleksyjnego, których celem jest polepszenie codziennego funkcjonowania. W przypadku trzeciorzedowej dysocjacji strukturalnej, tj. w sytuacji, w której rozwinęła się większa liczba cześci ANP, terapeuta stara się wzmacniać jakaś formę pozytywnej komunikacji i współpracy pomiędzy tymi cześciami, które funkcjonują w życiu codziennym. Celem tego zawsze jest pomaganie pacjentowi funkcjonować w sposób bardziej zintegrowany. Ogólnie rzecz ujmując, najważniejszym punktem wyjściowym wspomagania cześci ANP, a potem cześci EP, jest psychoedukacja o wartościach, wnoszonych przez inne cześci i przydatnych w codziennym życiu i przetrwaniu; ma to odniesienie nawet do tych EP, które są autoagresywne albo imitują zachowania sprawców traumy. Wszystkie te cześci są zaangażowane $\mathrm{w}$ próby rozwiązania problemu, co może być postrzegane jako działania substytucyjne. Niezwykle pomocne dla terapeuty jest wyjaśnianie, że te cześci EP nadal żyją w czasie traumy i nie są zdolne odróżnić traumatycznej przeszłości od teraźniejszości (zakładając, że teraźniejszość jest bezpieczna) (Van der Hart i in. 2010).

W kontekście podkreślania przez terapeutów wartościumożliwiającychprzetrwanie, wykazywanych przez różne cześci, jednym ze sposobów inicjowania konstruktywnej komunikacji pomiędzy ANP a EP jest zachęcanie przez terapeute cześsi ANP do zadania (w trakcie sesji) pytania cześci EP i zasugerowania (jeśli jest to właściwe), aby inne cześci słuchały. Przykładem jest sugerowanie tego ANP, która słyszy groźby EP, rozkazujące jej nie mówić nic terapeucie o istnieniu innych cześci. W ten pośredni sposób terapeuta (pozostając w kontakcie $z$ ANP) może na przykład zachęcić EP do powiadomienia ANP czego potrzebuje, aby poczuć się bezpieczniej.

Jak pomóc ANP w zaakceptowaniu EP. W nastepnej kolejności, ale nadal $\mathrm{w}$ fazie stabilizacji, terapeuci starają się rozwinać akceptacje cześci EP przez ANP oraz szersze współdziałanie pomieddzy zdysocjowanymi cześciami (Kluft, 2006; Van der Hart i in., 2006). Istnieje kilka technik, które są pomocne w takim przypadku. Pozwalają one również poprawić samoregulacje, samouspokojenie oraz samoakceptacje, które są koniecznymi przesłankami przetwarzania traumy (Faza 2 leczenia odwołującego sie do faz). Jednakże tego typu techniki mogą czasami w niewielkim stopniu wkroczyć na terytorium tej drugiej fazy leczenia. Jedną z takich technik jest wizualizacja ,Kochającego Spojrzenia” Knipe'a (2007). Poprzez stymulowanie systemu troski części ANP, terapeuta tworzy warunki, w których ta czesść postrzega $z$ miłością i szacunkiem cześć EP - uprzednio unikaną i pogardzaną, tkwiąca w sytuacji wołania o przywiązanie lub przytłoczona wstydem. Podczas gdy ANP kieruje sie instrukcjami terapeuty, by patrzeć na inną, mniejszą cześć z miłością i troską, pacjent doświadcza stymulacji bilateralnej (BLS) i przetwarza (integruje) napływające myśli i przekonania. Na podstawie tej procedury, opracowano bardziej złożone podejście, mające na celu odtworzenie zdrowego schematu dbania o siebie u pacjenta (jako ANP) w stosunku do innych zdysocjowanych cześci (Gonzales \& Mosquera, 2012). W tej pracy ze wzorami dbania o siebie, pacjent jako ANP uczy sie identyfikować i rozpoznawać potrzeby każdej zdysocjowanej cześci, łącznie $z$ niemowlęca cześcią EP, a wewnetrzny system cześci otrzymuje wsparcie w zaspokojeniu tych potrzeb w taki sposób, by zachować lub ustanowić równowage pomiędzy różnymi potrzebami tych czesści.

Cześci dysocjacyjne mogą stopniowo uczyć sie, jak uznać się nawzajem bez nadmiernych reakcji fobicznych, a tym samym porzucić nieadaptacyjne działania substytucyjne. W dalszej kolejności, każda cześć może nauczyć sie, jak docenić rolęinnych cześci oraz (pod)systemów działania, które je motywuja, tym samym pomagając jednostce jako całości w przetrwaniu i powolnym rozwijaniu wewnettrznej empatii. Na końcu, cześci mogą rozpoczać bardziej efektywną współprace nad obowiązkami dnia codziennego i samoregulacja.

Wewnętrzne Miejsce Spotkań. Praca $\mathrm{z}$ wyobrażeniami, obejmująca wzajemne spotkania zdysocjowanych cześci może być bardzo pomocna w zrozumieniu i współpracy pomiędzy tymi cześciami. Dlatego też gdy fobia zostanie w pewnym stopniu przezwyciężona, terapeuci mogą polecić swym pacjentom utworzenie tzw. stołu dysocjacyjnego (Fraser, 1991, 2003) lub wewnettrznego miejsca spotkań (Boon i in., 2011; Gonzales \& Mosquera, 2012; Van der Hart i in., 2006). Może to być specjalne pomieszczenie, miejsce na łonie natury lub jakiekolwiek inne, zapewniajace poczucie bezpieczeństwa. Bardzo pomocne jest, gdy to ANP informuje o tym inne części, a terapeuta stanowi model komunikacji z pozostałymi cześciami za pośrednictwem ANP. Takie spotkania moga poczatkowo przybrać forme spotkań biznesowych, a dyskusje powinny rozpoczynać się od stosunkowo mało ważnych kwestii, jak np. tworzenie harmonogramu na dany dzień. Pozwala to przećwiczyć spotkania wewnętrzne oraz umiejętności podejmowania decyzji jako zespół. Takie spotkania mogą być wykorzystane bardziej konstruktywnie, jako spotkania bardziej osobiste i emocjonalne, podczas 
których można podzielić sie radosnymi przeżyciami lub też przygnębiającymi doświadczeniami i pocieszeniem. Miejsce spotkania może być przydatną płaszczyzną przekazywania orientacji czasowej oraz rozwoju współpracy i zrozumienia/ współczucia pomiędzy cześciami. Tego typu współpraca wewnętrzna jest bardziej prawdopodobna, jeśli zdysocjowane cześci potrafią się skoncentrować i kolektywnie dzielić sie swymi przeżyciami wewnętrznymi (w tym zasobami) które to przeżycia są powiązane $z$ teraźniejszością, a jednocześnie gdy strony izoluja traumatyczne wspomnienia i inne czynniki zakłócające. W literaturze EMDR proponuje sie różne warianty tej procedury (Bergmann, 2007; Forgash \& Copeley, 2007; Gonzales \& Mosquera 2012; Paulsen, 2007, 2009). Wewnętrzne miejsce spotkań oraz wyobrażeniowe bezpieczne miejsca (patrz kolejne podrozdziały) mogą stać się cześcią bardziej złożonej struktury, np. wewnętrznej wspólnoty (Van der Hart, 2012).

Zwalczanie blokad. Fobia wobec cześci dysocjacyjnych, objawiająca się w różnych punktach blokady, może być wielokrotnie poddawana procedurom typowym dla EMDR. Takie procedury mogą wspomóc rozwój wewnętrzny począwszy od konfliktu między częściami do wzajemnej empatii i współpracy (Gonzales \& Mosquera, 2012). Jednym z przykładów jest umożliwienie zdysocjowanej cześci nawiązania bardzo potrzebnego połączenia $z$ innym (pod)systemem działania, ujawnianym przez inną cześć. W takiej sytuacji terapeuta pomaga obu cześciom tymczasowo stopić się w jedna, co umożliwia tej stronie, która tego potrzebuje, uzyskać dostęp do tego (pod)systemu działania, a tym samym do potrzebnego działania. Przykładem może być nieśmiała ANP pacjenta $z$ DID, która poprzez tymczasowe połączenie sie $z$ agresywną EP może stać się bardziej asertywna w życiu codziennym (H. Matthess, komunikacja personalna, 5 czerwiec 2009 r.). Trudności w przeprowadzeniu tego typu interwencji można przezwyciężý za pomoca psychoedukacji i określonych procedur EMDR. Przykładowo, gdy czesść ANP obawia się agresywnej i głośnej EP oraz nie potrafi odczuwać jakiejkolwiek empatii w stosunku do takiej EP, wówczas terapeuta może zachęcić ANP do przyjrzenia się EP, omówienia uczuć, które odczuwa w stosunku do niej i zwrócenia uwagi na swe doznania. Krótka stymulacja bilateralna (BLS) takiego doznania, może przynajmniej częściowo odblokować impas, bądź poprzez ułatwienie zmniejszenia negatywnego doznania bądź poprzez zwiększenie refleksyjnego funkcjonowania w ANP. Niemniej jednak zaleca się ostrożność, gdyż stymulacja bilateralna może skutkować zwiększeniem dystresu. Gdy niechęć ANP do dialogu z EP zmniejszy sie, terapeuta może zaproponować podobną możliwość EP. W ten sposób można poprawić wewnętrzną współprace i komunikacje poprzez ostrożne stosowanie BLS w celu usunięcia określonych „punktów blokujących” (Gonzales \& Mosquera, 2012).

\section{Przezwyciężanie fobii wobec części imitujących sprawce}

Powtarzane przez terapeutów wyjaśnienia na temat wartości ułatwiających przetrwanie, przejawianych przez inne cześsi - zwłaszcza przez te najbardziej przerażające lub pogardzane - oraz na temat interakcji między nimi, pozwalają uczyć inne zdysocjowane cześci, że możliwa jest pozytywna interakcja z tymi cześciami i że przynosi ona korzyści wszystkim cześciom uczestniczącym $\mathrm{w}$ tym procesie, a także kształtuje pozytywne umiejętności interpersonalne. Ważnym przykładem może być sytuacja, kiedy czesści ANP i EP odczuwają ekstremalny strach przed czéściami imitującymi sprawcę, określanymi również jako prześladowca, sprawca lub czesść (czesści) prześladowcze (Kluft, 2006; Ross, 1997, Van der Hart i in., 2006): zdysocjowane cześci, które imitują rzeczywistych sprawców i czesto są traktowane jako sprawcy przez inne cześci. Konieczna jest powtarzająca się psychoedukacja lub eksploracja pierwotnej funkcji przetrwania tych cześci; przykładowo dostrojenie sie do działań i (re) akcji sprawcy wobec pacjenta jako dziecka oraz próba zapobieżenia tym działaniom i reakcjom poprzez karanie innych cześci w taki sposób, jaki zaobserwowały u tych sprawców (np. maltretujących i poniżających rodziców). Cześci te mogą posiadać umiejętności funkcjonalne, takie jak kontrola lub siła, ale zazwyczaj cześć ANP pacjenta odrzuca je, a inne EP boją się ich, gdyż przypominają im o cechach osobowości sprawcy oraz o przykrych doświadczeniach. Zakłóca to korzyści wynikające $z$ terapii. Realizacja $\mathrm{w}$ formie odróżniania prawdziwego zewnętrznego sprawcy od jego/jej wewnętrznego obrazu jest niezbeedna dla osiagnięcia postępu w terapii (Paulsen, 2009; Van der Hart $i$ in. 2006).

Cześci imitujące sprawce, ale nie tylko, są czesto uwikłane w zachowania autodestrukcyjne, naruszanie granic $\mathrm{w}$ kontaktach $\mathrm{z}$ innymi ludźmi lub też $\mathrm{w}$ trwające dreczenie fizyczne lub seksualne. Ponownie należy podkreślić i zrozumieć, że tego typu działania destrukcyjne, pomijając ich niewłaściwość, sąpróbami rozwiązania problemów powstałych w ekstremalnych (traumatycznych) okolicznościach. Terapeuci muszą rozpoznać i uznać pierwotną funkcje przetrwania oraz pomóc ANP w porozumieniu sie $z$ takimi cześsciami i zachęceniu ich do alternatywnych, mniej destrukcyjnych lub raczej konstruktywnych 
rozwiązań (C.A.Ross, 1997). Jedną z podstawowych czynności jest wytłumaczenie, że cześci EP nadal żyją $\mathrm{w}$ traumie i reagują na wyzwalacze w ten sam sposób, w jaki reagowały w przypadku faktycznej traumy. Kolejnym krokiem może być pomoc tym cześciom $\mathrm{w}$ większym zorientowaniu sie $\mathrm{w}$ teraźniejszości: ich uobecnienie (prezentyfikacja) (patrz kolejne rozdziały). System osobowościowy pacjenta jako całość może stać się znacznie bardziej zdolny do współpracy, rozwiązywania problemów i podejmowania adaptacyjnych decyzji.

Przezwyciężanie fobii wobec młodych, słabych części

Gdy cześć ANP lub dominująca, agresywna czesść EP pogardza i odrzuca wrażliwe i słabe cześci dziecięce, objaśnienia terapeuty na temat (pod)systemów działania, które pośredniczą w funkcjach przetrwania takich cześci, mogą być zasadniczym elementem sprzyjającym wiekkszej akceptacji i szacunkowi wobec takich cześci. Przykładem może być walcząca cześć EP kobiety z DID, która w wieku 17 lat stała sie ofiara gwałtu zbiorowego. W czasie gwałtu, walcząca EP została zastąpiona cześcią dziecięca, która uległa licznym sprawcom. Terapeuta, reagując na obrzydzenie walczącej EP względem cześci dziecięcej, zapytał: „Czy zdajesz sobie sprawe, co mogłoby sie stać, gdybyś kontynuowała walke, a dziecięca cześć nie przejęłaby kontroli?” Po kilku chwilach ciszy, walcząca cześść, wyraźnie zszokowana, odpowiedziała: „Wtedy zostałybyśmy zabite”. Kolejnym krokiem była kierowana akceptacja uprzednio pogardzanej cześci dziecięcej. Innym przykładem jest kobieta wykorzystywana seksualnie w dzieciństwie przez swojego ojca. Kobieta posiadała agresywna cześć EP, która nie tolerowała dziecięcej EP, silnie przywiązanej do sprawcy. Obu stronom pomogła ANP, umożliwiając im doświadczenie siebie nawzajem jako niezbednych sobie i uosabiających oczywiste przeciwstawne tendencje wobec ojca. W nastepstwie psychoedukacji, ANP była w stanie zrozumieć punkt widzenia obu części EP (potrzebe więzi w przypadku cześci dziecięcej oraz nienawiść drugiej cześci EP). Jako osoba dorosła, kobieta zrozumiała, że jej najlepszą opcją w dzieciństwie było rozdzielenie sie, aby móc odnieść się do siebie. Taką integrująca perspektywe można wzmocnić za pomocą krótkich stymulacji bilateralnych.

Reasumując, jest rzeczą zasadnicza, by pacjent rozumiał i uczył się stosować kluczową zasade stopniowej akceptacji, uznania i urzeczywistniania cześci EP i ANP jako cześci tej samej osobowości oraz że każda cześć jest odpowiedzialna tak przed pozostałymi cześciami osobowościami jak i za nie. W przeciwnym wypadku pewne cześci pacjenta mogą wykorzystać osobe terapeuty jako „nianię" - np. wykorzystać sesję terapeutyczną jako okazję do wypłakania się i uzyskania empatycznego współczucia, bez czynienia postępów - taka osobowość może też oczekiwać od terapeuty pozbycia sie, ukarania lub kontrolowania innych zdysocjowanych cześci zamiast wziąć osobistą odpowiedzialność za ich działania, które przecież tworzą pacjenta jako całość.

\section{Uaktywnianie zasobów}

Rozwijanie i instalacja zasobów (RDI - Resource Development and Installation) jest szeroko stosowanym rodzajem interwencji w terapii EMDR (Korn \& Leeds, 2002). Jednak w przypadku pacjentów, którzy doświadczyli złożonej traumy, koncepcja zasobów wymaga rozszerzenia. Uaktywnianie zasobów obejmuje aktywowanie zasobów emocjonalnych, poznawczych, sensomotorycznych i relacyjnych, strategie wzmacniające ego oraz interwencje wzmacniające pacjenta. Bardzo ważna jest również praca mająca na celu podstawowe zarządzanie energią (odpowiednia ilość snu, odpoczynku, pożywienia), rozwój zasobów somatycznych, takich jak ugruntowanie oraz uważna świadomość własnego ciała, a także inne zastosowania doświadczeń psychomotorycznych w celu ustanowienia granic i regulacji (Ogden i in., 2006).

RDI, podobnie jak każda inna interwencja w przypadku pacjentów ze złożoną dysocjacją osobowości, powinno być przeprowadzane za zgodą całego systemu cześci. Jednym z przykładów jest sytuacja, w której pacjentka przejawiała fobie przed opuszczeniem jej przez figury rodzicielskie (włącznie $z$ terapeutą). Zapytana o to, czego potrzebuje, by zmniejszyć swe pobudzenie, gdy zostaje sama $\mathrm{w}$ pokoju, pacjentka odparła: „Wiary w połączenie, w wieź.” Cześć ANP zaprosiła inne cześci do udziału w ćwiczeniu, na co czesści te wyraziły zgode. Pacjentka narysowała symbol tej wiary: dwie dłonie splecione razem. W czasie, gdy pacjentka trzymała rysunek, terapeuta za pomocą stymulacji bilateralnej zainstalował ten zasób w ANP, sugerując jednocześnie, by czesść ANP utrzymywała kontakt $\mathrm{z}$ cześciami EP, $\mathrm{z}$ którymi dzieliła te same odczucia.

\section{Orientacja czasowa}

Specyficzną procedurą uaktywniania zasobów, która jest najważniejsza w rozwijaniu podwójnej uwagi, jest orientacja czasowa. Jak wspomniano wcześniej, czesść EP zazwyczaj żyje w czasie traumy, a tym 
samym nie odróżnia przeszłości od teraźniejszości. Terapeuta, rozmawiając $z$ taką EP za pośrednictwem cześci ANP, oraz stosując krótkotrwałe stymulacje bilateralne, jest $\mathrm{w}$ stanie do pewnego stopnia uświadomić takiej osobowości prawdziwą date oraz że niebezpieczeństwo minęło (np. Czy ta czesść wie, że jest rok 2013. . . że jesteś osobą dorosła. . . i że niebezpieczeństwo mineło i nie grozi w tej chwili?). Można dodać różne inne rodzaje interwencji, np. zachęcenie czesści EP do spojrzenia na dłoń pacjenta, na której ten nosi obrączke, lub też sprawdzenie daty na gazecie lub terminarzu. Włączenie krótkich okresów stymulacji bilateralnej może wzmocnić współświadomość, zmniejszyć napięcie i zwiększyć integracje, obejmująca łączenie informacji adaptacyjnych. Wskazana jest jednak ostrożność, by nie wydobyć materiału przekraczającego okno tolerancji pacjenta. Jeśli zaczną pojawiać się negatywne uczucia, należy przerwać BLS. Dodatkowo, w takiej sytuacji potrzebna jest dalsza eksploracja, by zrozumieć, co sie dzieje; oraz/ lub wprowadzenie ugruntowania/ stabilizacji, by utrzymać pacjenta w oknie tolerancji. W podobny sposób można za pomocą krótkich stymulacji bilateralnych wzmocnić pozytywne emocje współczucia lub inne uczucia adaptacyjne jednej części (np. ANP)w stosunku do innej (np. EP).

\section{Wyobrażenie bezpiecznego miejsca}

Wyobrażenie bezpiecznego i cichego miejsca może pomóc cześciom $\mathrm{w}$ radzeniu sobie $\mathrm{z}$ przewidywalnymi sytuacjami wyzwalającymi w codziennym życiu, a także z przykrymi wspomnieniami, przekonaniami, dyskusjami między stronami, które mogą wyzwolić traumatyczne wspomnienia, oraz z innymi elementami wzbudzającymi strach. Proces wyobrażenia obejmuje obrazy miejsca, gdzie pacjent czuje sie bezpiecznie i pod ochroną, lub też, jeśli koncepcja i doświadczanie bezpieczeństwa ciągle jeszcze nie jest mu znane, miejsce, w którym czują się stosunkowo swobodnie (Brown \& Fromm, 1986; Van der Hart i in., 2006). Instalacja bezpiecznego miejsca jest dobrze znanym typem interwencji wśród terapeutów EMDR (np. Gelinas, 2003; Korn \& Leeds, 2002; O’Shea, 2009). W przypadku pacjentów dysocjacjujących, technika ta może być zastosowana na różne sposoby, jak na przykład tworzenie bezpiecznego miejsca dla cześci dziecięcej, która nie powinna uczestniczyć w interakcjach pacjenta $z$ innymi ludźmi lub w wewnętrznych rozmowach między czesściami. W niektórych przypadkach, bezpieczne miejsce może służyć grupom zdysocjowanych cześci jako miejsce spotkań, lub też każda czesść może posiadać własne miejsce.
Sytuacja przykładowa: pacjent musiał od czasu do czasu zmierzyć się z natrętnymi wizytami swych rodziców, którzy komentowali w bardzo negatywny sposób wszystko, co zauważyli w pacjencie i w jego mieszkaniu. Pacjent posiadał asertywną czesść ANP, jednak przybycie rodziców natychmiast wyzwalało pojawianie się bardzo uległej dziecięcej cześci EP, która ze strachem była posłuszna rodzicom w każdym aspekcie. Stworzenie bezpiecznego miejsca dla dziecięcych cześci - do którego mogły być one wysyłane przez cześć ANP w razie potrzeby - było jednym ze sposobów, by pacjent poradził sobie $z$ ingerencjami rodziców. Innym sposobem było stworzenie przez ANP wyobrażenia płaszcza ochronnego, który zwiększył pewność pacjenta $\mathrm{w}$ radzeniu sobie $\mathrm{z}$ tym trudnym wyzwaniem (Boon i in., 2011; Van der Hart, 2012).

Jednak gdy terapeuta stosuje takie techniki stabilizacyjne bez świadomości wewnętrznego systemu zdysocjowanych cześci, bez uprzedniego sprawdzenia, czy wszystkie strony są zgodne co do przeprowadzenia procedury oraz bez odpowiedniego zrozumienia charakterystyki pacjentów z cięzką traumą, wówczas skutki mogą być przeciwne do zamierzonych. Przykładowo, wroga czesśc może odbierać pomoc cześci EP w znalezieniu bezpiecznego miejsca jako próbę wyrwania się spod jej kontroli i będzie przeszkadzać w utworzeniu takiego miejsca. Możliwa jest też sytuacja, w której słowo „bezpieczny” może stanowić wyzwalacz na zasadzie skojarzenia ze stwierdzeniem „jak niebezpieczne było moje dzieciństwo”. Pacjent może odczuć udręke nawet uzmysławiając sobie, jak wielu potrzebnych rzeczy mu brakowało. Lub też pacjent, którego cześś ANP nie zdaje sobie sprawy $z$ traumatycznych doświadczeń, może wybrać jako bezpieczne miejsce to pomieszczenie (w którym był wykorzystywany) $z$ domu rodzinnego.

\section{Inne zastosowania uaktywniania zasobów}

Jak wspomniano wcześniej, można rozważyć zastosowanie instalacji zasobów w szerokim zakresie w przypadku pacjentów z historią złożonej traumy. RDI może być przydatna nie tylko dla głównej części ANP, ale również dla innych zdysocjowanych części (w tym EP). Dla cześci ANP, przykłady potrzebnych zasobów to samoregulacja, stałość obiektu, odwaga, współczucie w ramach wewnętrznego systemu oraz pewność siebie. Dla cześci EP, głównie ujawnianej przez podsystem działań obronnych, potrzebne zasoby lub umiejętności będą odnosić się do doświadczonego bezpieczeństwa, przywiązania, siły, proaktywnego, adaptacyjnego i zaradnego stylu oraz do orientacji w teraźniejszości. Aby RDI było 
udane $\mathrm{w}$ takich przypadkach, często wcześniej potrzebna może być praca w przezwyciężaniu różnych fobii podtrzymujących dysocjacje, takich jak fobia przed zdysocjowanymi cześciami. Przykładowo, gdy wzmacnia się część ANP, cześci EP mogą odczuwać, że ich wewnętrzny przeciwnik otrzymuje pomoc w zwieksszaniu swojej siły, a tym samym w odniesieniu zwycięstwa na innymi cześsiami. Dlatego też, gdy terapeuta próbował zainstalować zasób u pacjentki, u której zdiagnozowano depresje (terapeuta nie wiedział, że pacjentka ma DDNOS) - pacjentka usłyszała głos, krzyczaç w jej głowie „Jeśli dasz jej [ANP] więcej energii, będziesz mieć do czynienia ze mną [EP].” Gdy terapeuta ma świadomość dysocjacji osobowości pacjenta, może to zapobiec takim sytuacjom, zwiększając tym samym bezpieczeństwo i efektywność interwencji.

\section{Wnioski}

TSDP oraz AIP sa kompatybilnymi modelami pracy z pacjentami, którzy doświadczyli traumy. Modele te moga się wzajemnie uzupełniać. $Z$ jednej strony TSDP zapewnia wszechstronne ramy dla lepszego zrozumienia skomplikowanego i dysocjacyjnego świata wewnętrznego pacjentów $\mathrm{z}$ zaburzeniami wynikającymi ze złożonej traumy, oraz dla przeprowadzenia konceptualizacji danego przypadku. Leczenie odwołujące sie do faz, szeroko akceptowane w zakresie zaburzeń związanych ze złożoną trauma, kładzie nacisk na znaczenie odpowiedniej fazy stabilizacji, w tym redukcję objawów, budowanie umiejętności oraz ustanawianie bezpiecznej więzi terapeutycznej. Może to zapewnić terapeutom EMDR ważne zasoby, przydatne do przygotowania bezpiecznego i efektywnego przetwarzania traumy. Z drugiej strony, włączenie niektórych procedur EMDR, w tym BLS, podczas fazy stabilizacji może skrócić i wzmocnić proces terapeutyczny. W niniejszym artykule przedstawiono połaczenie koncepcji teorii TSDP i określonych procedur EMDR. Podkreśla się tym samym ważność uaktywniania zasobów (resourcing) oraz zasade TSDP dotycząca zmiany tak zwanych „przekonań substytucyjnych”, które zajmują miejsce bardziej adaptacyjnych i integracyjnych działań psychicznych i behawioralnych. Głównymi formami przekonań substytucyjnych oraz powiązanych działań psychicznych i behawioralnych są różne fobie dysocjacyjne. Niektóre $z$ nich wymagaja systematycznej pracy podczas fazy stabilizacji. Reasumując, dzięki stosowaniu tych podstawowych elementów, pacjenci uzyskają gotowość do przetwarzania przy pomocy EMDR (w nomenklaturze TSDP - syntezy i realizacji) wspomnień traumatycznych. Zagadnienie to jest głównym tematem kolejnego artykułu.

\section{Piśmiennictwo}

Allen, J. G., Fonagy, P., \& Bateman, A. W. (2008). Mentalizing in clinical practice. Washington, DC: American Psychiatric Publishing.

American Psychiatric Association. (1994). Diagnostic andstatistical manual of mental health disorders (4th ed.). Washington, DC: Author.

Bergmann, U. (2007). Hidden selves: Treating dissociation in the spectrum of personality disorders. In C. Forgash \& M. Copeley (Eds.), Healing the heart of trauma and dissociation with EMDR and ego state therapy (pp. 181-225). New York, NY: Springer Publishing.

Boon, S. (1997). The treatment of traumatic memories in DID: Indications and contraindications. Dissociation, 10, 65-79.

Boon, S., \& Draijer, N. (1993). Multiple personality disorder inthe Netherlands. Lisse, The Netherlands: Swets \& Zeitlinger.

Boon, S., Steele, K., \& Van der Hart, O. (2011). Coping with trauma-related dissociation: Skills training for clients and therapists. New York, NY: Norton.

Brown, D. P., \& Fromm, E. (1986). Hypnotherapy and hypnoanalysis. Hillsdale, NJ: Lawrence Erlbaum Associates.

Brown, D., Scheflin, A. W., \& Hammond, D. C. (1998). Memory, trauma treatment, and the law. New York, NY: Norton.

Courtois, C. A. (1999). Recollections of sexual abuse: Treatmentprinciples and guidelines. New York, NY: Norton.

Dell, P. F. (2009). Understanding dissociation. In P. F. Dell \& J. A. O’Neil (Eds.), Dissociation and dissociative disorders:DSM-IV and beyond (pp. 709-825). New York, NY:Routledge.

Fine, C. G., \& Berkowitz, A. S. (2001). The wreathing protocol:The imbrications of hypnosis and EMDR in the treatment of dissociative identity disorder and other dissociative responses. American Journal of Clinical Hypnosis, 43, 275-290.

Forgash, C., \& Copeley, M. (Eds.). (2007). Healing the heart of trauma and dissociation with EMDR and ego state therapy. New York, NY: Springer Publishing.

Forgash, C., \& Knipe, J. (2007). Integrating EMDR and ego state treatment for clients with trauma disorders. In C. Forgash \& M. Copeley (Eds.), Healing the heart of trauma and dissociation with EMDR and ego state therapy (pp. 1-59). New York, NY: Springer Publishing.

Fraser, G. A. (1991). The dissociative table technique: A strategy for working with ego states in dissociative identity disorder and ego-state therapy. Dissociation, 4, 205-213.

Fraser, G. A. (2003). Fraser's "dissociative table technique" revisited, revised: A strategy for working with ego states in dissociative disorders and ego-state therapy. Journal of Trauma and Dissociation, 4(4), 5-28.

Gelinas, D. J. (2003). Integrating EMDR into phase-oriented treatment for trauma. Journal of Trauma \& Dissociation, 4(3), 91-135. 
Gonzalez, A., \& Mosquera, D. (Eds.). (2012). EMDR and dissociation:The progressive approach. Charleston, SC: Amazon Imprint.

Herman, J. L. (1992). Trauma and recovery. New York, NY: Basic Books.

Hofmann, A. (2006). EMDR in der Behandlung psychotraumatischer Belastungssyndrome [EMDR therapy with posttraumatic stress syndrome]. Stuttgart, Germany: Thieme.

International Society for the Study of Trauma and Dissociation. (2011). Guidelines for treating dissociative identity disorder in adults, third revision: Summary version. Journal of Trauma \& Dissociation, 12(2), 115-187.

Janet, P. (1897). Traitement psychologique de l'hystérie. In A. Robin (Ed.), Traité de thérapeutique appliquée. Paris, France: Rueff.

Janet, P. (1904). L'amnésie et la dissociation des souvenirs par l'émotion [Amnesia and the dissociation of memories by emotion]. Journal de Psychologie, 1, 417-453.

Janet, P. (1909). Problčmes psychologiques de l'émotion. Revue Neurologique, 17, 1551-1687.

Janet, P. (1925). Psychological healing. New York, NY: Macmillan.

Johnson, J. G., Cohen, P., Kasen, S., \& Brook, J. S. (2006). Dissociative disorders among adults in the community, impaired functioning, and axis I and II comorbidity. Journal Psychiatric Research, 40, 131-140.

Kluft, R. P. (1993). The initial stages of psychotherapy in the treatment of multiple personality disorder. Dissociation, 6, 145-161.

Kluft, R. P. (1997). The initial stages of psychotherapy in the treatment of multiple personality disorder. Dissociation, 10, 145-161.

Kluft, R. P. (1999). An overview of the psychotherapy of dissociative identity disorder. American Journal of Psychotherapy, 53, 289-319.

Kluft, R. P. (2006). Dealing with alters: A pragmatic clinical perspective. Psychiatric Clinics of North America, 29, 281-304.

Knipe, J. (2007). Loving eyes: Procedures to therapeutically reverse dissociative processes while preserving emotional safety. In C. Forgash \& M. Copeley (Eds.), Healing the heart of trauma and dissociation with EMDR and ego state therapy (pp. 181-225). New York, NY: Springer Publishing.

Korn, D. L. (2009). EMDR and the treatment of complex PTSD. Journal of EMDR Practice and Research, 3, 264-278.

Korn, D. L., \& Leeds, A. M. (2002). Preliminary evidence of efficacy for EMDR resource development and installation in the stabilization phase of treatment of complex posttraumatic stress disorder. Journal of Clinical Psychology, 58, 1465-1487.

Lazrove, S., \& Fine, C. G. (1996). The use of EMDR in clients with dissociative identity disorder. Dissociation, 9 , 289-299.

Linehan, M. M. (1993). Cognitive behavioral treatment of borderlinepersonality disorder. New York, NY: Guildford Press.
Liotti, G. (1999). Disorganization of attachment as a model for understanding dissociative psychopathology. In J. Solomon \& C. George (Eds.), Attachment disorganization (pp. 297-317). New York, NY: Guilford Press.

Luber, M., \& Shapiro, F. (2009). Interview with Francine Shapiro: Historical overview, present issues, and future directions of EMDR. Journal of EMDR Practice and Research, 3, 217-231.

Nijenhuis, E. R. S., \& Den Boer, J. A. (2009). Psychobiology of traumatization and trauma-related structural dissociation of the personality. In P. F. Dell \& J. A. O’Neil (Eds.), Dissociation and dissociative disorders: DSM-IV and beyond (pp. 337-365). Oxford, United Kingdom: Routledge.

Nijenhuis, E. R. S., \& Van der Hart, O. (2011). Dissociation in trauma: A new definition and comparison with previous formulations. Journal of Trauma and Dissociation, 12, 416-445.

Nijenhuis, E. R. S., Van der Hart, O., \& Steele, K. (2002). The emerging psychobiology of trauma-related dissociation and dissociative disorders. In H. D'Haenen, J. A. den Boer, \& P. Willner (Eds.), Biological psychiatry (pp. 1079-1098). London, United Kingdom: Wiley.

Ogden, P., Minton, K., \& Pain, C. (2006). Trauma and the body: A sensorimotor approach to psychotherapy. New York, NY: Norton.

O'Shea, K. (2009). EMDR friendly preparation methods for adults and children. In R. Shapiro (Ed.), EMDR solutions II: For depression, eating disorders, performance, and more (pp. 289-312). New York, NY: Norton.

Paulsen, S. (2007). Treating dissociative identity disorder with EMDR, ego state therapy, and adjunct approaches. In C. Forgash \& M. Copeley (Eds.), Healing the heart of trauma and dissociation with EMDR and ego state therapy (pp. 141-179). New York, NY: Springer.

Paulsen, S. (2009). Act-as-if and architects approaches to EMDR treatment of DID. In M. Luber (Ed.), Eye movement desensitization and reprocessing (EMDR) scripted protocols:Special populations (pp. 357-387). New York, NY: Springer.

Putnam, F. W., Guroff, J. J., Silberman, E. K., Barban, L., \& Post, R. M. (1986). The clinical phenomenology of multiple personality disorder: Review of 100 recent cases. Journal of Clinical Psychiatry, 47, 285-293.

Ross, C. A. (1997). Dissociative identity disorder: Diagnosis, clinical features, and treatment of multiple personality. New York, NY: Wiley.

Ross, T. A. (1941). War neuroses. Baltimore, MD: Williams \& Wilkins.

Şar, V., Akyuz, G., \& Dogan, O. (2007). Prevalence of dissociative disorders among women in the general population. Psychiatry Research, 149, 169-176.

Shapiro, F. (1995). Eye movement desensitization and reprocessing:Basic principles, protocols, and procedures. New York, NY: Guilford Press.

Shapiro,F.(2001).Eyemovementdesensitizationandreprocessing: Basic principles, protocols, and procedures (2nd ed.). New York, NY: Guilford Press. 
Solomon, R., \& Shapiro, F. (2008). EMDR and the adaptive information processing model: Potential mechanisms of change. Journal of EMDR Practice and Research, 4, 315-325.

Steele, K., Van der Hart, O., \& Nijenhuis, E. R. S. (2001). Dependency in the treatment of complex posttraumatic stress disorder and dissociative disorders. Journal of Trauma and Dissociation, 2(4), 79-116.

Steele, K., Van der Hart, O., \& Nijenhuis, E. R. S. (2005). Phase-oriented treatment of structural dissociation in complex traumatization: Overcoming trauma-related phobias. Journal of Trauma and Dissociation, 6(3), 11-53.

Twombly, J. H. (2000). Incorporating EMDR and EMDR adaptations into the treatment of clients with dissociative identity disorder. Journal of Trauma \& Dissociation, 1(2), 61-80.

Twombly, J. H. (2005). EMDR for clients with dissociative identity disorder, DDNOS, and ego states. In R. Shapiro (Ed.), EMDR solutions: Pathways to healing (pp. 88-120). New York, NY: Norton.

Van der Hart, O. (2012). The use of imagery in phase 1 treatment of clients with complex dissociative disorders.
European Journal of Psychotraumatology, 3, 8458. http:/ / dx.doi.org/10.3402/ ejpt.v3i0.8458

Van der Hart, O., Brown, P., \& Van der Kolk, B. A. (1989). Pierre Janet's treatment of post-traumatic stress. Journal of Traumatic Stress, 2, 379-396.

Van der Hart, O., Nijenhuis, E. R. S., \& Solomon, R. M. (2010). Dissociation of the personality in complex trauma-related disorders and EMDR: Theoretical consideration. Journal of EMDR Practice and Research, 4, 76-92.

Van der Hart, O., Nijenhuis, E. R. S., \& Steele, K. (2006). The haunted self: Structural dissociation and the treatment of chronic traumatization. New York, NY: Norton.

Van der Hart, O., Steele, K., Boon, S., \& Brown, P. (1993). The treatment of traumatic memories: Synthesis, realization and integration. Dissociation, 6, 162-180.

Korespondencja odnosząca się do niniejszego artykułu powinna być kierowana do Onno van der Hart, PhD, Department of Clinical and Health Psychology, Utrecht University, Heidelberglaan 1, 3584 CS Utrecht, The Netherlands. E-mail: o.vanderhart@uu.n 